EDITORIAL

\title{
CONTROLE DE GASTOS PÚBLICOS VIA LICITAÇÃO: O QUE NÃO SE AFINA COM OS PRINCÍPIOS DA BOA GOVERNANÇA?
}

Em regra, quando se fala em gestão pública no Brasil, conceitos como ineficiência e malversação de recursos parecem emergir com tanta naturalidade como a convicção de que mudanças nessa área são necessárias. Apesar disso, ninguém se julga em condições de adotar as providências cabíveis sem antes submetê-las a longos debates, que não raro se esgotam na simples produção de novas leis ou nas conhecidas reformas administrativas.

É perfeitamente compreensível e necessário que num Estado de Direito a ação dos gestores públicos esteja subordinada a um quadro normativo de observância obrigatória. Esse é o pressuposto fundamental do próprio Estado de Direito. Entretanto, é preciso considerar que leis, por si só, não garantem a eficácia da gestão e não produzem mudança de mentalidade, principalmente quando encerram conteúdos que não se afinam com as boas regras de governança. Exemplo disso é a chamada Lei das Licitações, cuja contribuição para a otimização de compras realizadas pelo setor público parece ser cada vez mais questionada.

Estruturada sob os impactos de diversos escândalos administrativos, a referida Lei tem por finalidade selecionar a proposta mais vantajosa e proporcionar iguais oportunidades àqueles que desejam contratar com a Administração Pública. Em regra, o julgamento do que é mais vantajoso, no espírito da lei, fica subordinado ao critério do menor preço e à observância dos princípios da legalidade, igualdade, impessoalidade, moralidade e publicidade.

No meio empresarial, não surpreendentemente, esse tipo de julgamento seria muito mais simples e objetivo, pois normalmente considera-se como mais vantajosa a proposta que apresenta o menor custo total do ciclo de vida dos produtos a certo nível de qualidade. Esse é o entendimento predominante porque, racionalmente, os consumidores tendem a escolher produtos e serviços não apenas em função de preço, mas considerando também outros fatores relevantes como o custo de operação, manutenção e descarte. Tanto é assim que as empresas procuram concorrer não apenas em preço, mas buscando diferenciação em qualidade, serviços ao cliente, nível de tecnologia e outros elementos que contribuam para distinguir seus produtos e serviços. Mesmo para aquelas que buscam diferenciação em custo, as possibilidades de criar vantagem competitiva quase nunca se resumem ao preço dos bens e serviços, mas tem como alvo a estimativa do volume de recursos que será arcado pelo consumidor até o fim do ciclo de vida do produto.

Não se pode negar que a intenção da referida lei realmente tenha sido garantir a seleção de propostas mais vantajosas para o erário público. Porém, é igualmente inegável que, sob o prisma da economicidade, princípio que também deve reger a Administração Pública, a lei ainda peca por eleger o fator preço como o principal critério de decisão.

É certo que o preço dos bens e serviços é o componente mais visível do custo do ciclo de vida dos produtos, mas raramente é o único e nem necessariamente o mais importante. Qualquer gestor medianamente instruído reconhece, por exemplo, que no caso de máquinas e equipamentos os custos mais significativos estão relacionados com manutenção e utilização dos bens ao longo de sua vida útil. Em tais circunstâncias, as decisões de compra devem considerar outros fatores além do preço de aquisição, tais como o nível de serviços pós-venda, o custo de operação e manutenção, a 
disponibilidade de assistência técnica, entre outros. Este é um dos aspectos de governança que não se considera na sistemática de compras adotada pelo setor público. O entendimento legal é o de que a Administração deve se ater ao mínimo de especificações necessárias para que se possam obter propostas comparáveis ante um critério de julgamento aplicável a todas. Logo, todos os cuidados que normalmente se adotam à exaustão na iniciativa privada a fim de obter o melhor produto ou serviço ao menor custo possível são tratados na gestão pública como tentativa de singularização viciosa do objeto da licitação.

Esse impedimento legal de particularizar "excessivamente" os bens e serviços a serem adquiridos tem como pressuposto a existência de um mercado baseado em concorrência perfeita, ou seja, supõe-se que o produto de um vendedor é absolutamente idêntico ao produto comercializado pelos demais. Ora, a teoria econômica deixa claro que mesmo nos mercados capitalistas mais avançados as forças competitivas não estão circunscritas ao mundo dos produtos homogêneos e nem à existência de um número muito grande de produtores, como supõe a Lei das Licitações. Na prática, cada empresa, de uma forma ou de outra, procura diferenciar seu produto para que ele se torne único. Essa diferenciação pode se manifestar de tantas maneiras que o preço se torna apenas uma delas, e muitas vezes a menos relevante.

A princípio, pode-se imaginar que as entidades governamentais não precisam se preocupar tanto com as decisões de compra quanto as organizações orientadas para o lucro. Porém, há de se considerar que assim como estas precisam otimizar a aplicação de seus recursos para assegurar o cumprimento de sua missão e oferecer retorno compatível com as expectativas dos acionistas, as primeiras também devem gastar racionalmente para garantir o cumprimento de seus objetivos com o menor grau de sacrifício possível para o contribuinte.

Dada a importância que o problema ora exposto assume no campo da gestão pública e a carência de estudos que explorem as deficiências do atual modelo de licitação, esperamos que esta modesta reflexão possa estimular novos esforços de pesquisa nessa área. Acreditamos ser necessário empreender alguns passos mais vigorosos nessa direção por considerar que a construção de uma sociedade moderna e democrática exige que as atividades governamentais se baseiem nos princípios de eficiência e eficácia. Sim, porque essa é uma condição fundamental para que os benefícios sociais se ampliem e alcancem o maior número de cidadãos ao menor custo possível.

José Maria Dias Filho

Professor Doutor da Faculdade de Ciências Contábeis da UFBA 